\title{
The Provision of International Public Goods: Japan's Anti-Piracy Operations in the Gulf of Aden
}

I will carry forward a diplomacy which contributes to world peace, so that Japan will realize its responsibilities commensurate with its national strength in the international community, and become a country which is relied upon internationally.

Policy Speech by Prime Minister Yasuo Fukuda to the 169th Session of the Diet, January 182008

\section{Piracy as a Security Challenge}

As discussed in Chap. 4, the Middle East is one of the most important regions in the world to Japan, considering that a huge bulk of Japan's energy supplies come from the area. According to Japan's Ministry of Economy, Trade and Industry's Agency for Natural Resources and Energy, in 2015, Middle Eastern countries supplied about 78\% of Japan's 1.23 billion barrels of crude oil. The most important countries that provide for Japan's energy needs are as follows: Saudi Arabia (33\%), UAE (25\%), Qatar (8\%), Kuwait (8\%), Iran (5\%) and Iraq (2\%). Since the oil crisis in the 1970s, Japan's relationship with the Middle Eastern world, particularly the Arab states, has moved beyond a "buyer-seller" relationship, with Japan building political relations with much of the Arab world. Japan has also undertaken steps to source energy products from alternative markets such as Venezuela, Mexico and Indonesia, as well as diversify on the types 
of energy it uses. Needless to say, Tokyo has always been extremely concerned about the freedom and security of the shipping lanes from the Middle East to East Asia. By 2014, due to the Great East Japan Earthquake in 2011, Japan was forced to increase reliance on energy imports (oil/ gas/coal) up to $88 \%$. Thus, undertaking measures to secure its energy imports became more important than ever. This is why Japan has quietly been struggling to maintain a common position with the US over Iran and has assiduously cultivated the various Gulf states by increasing its engagement with the Arab states.

Beyond the issue of securing energy imports, Japan has also been undertaking other activities in the region. First, the JSDF has engaged in humanitarian and peacekeeping missions. In the aftermath of the Gulf War, Japan deployed four wooden-hull naval vessels to help in minesweeping operations (Woolley 1996). Japanese troops have been deployed on UN peacekeeping missions to Angola (1992), the Golan Heights (1996-2012), Sudan (2012-present). Japan participated in international humanitarian relief operations in such countries as Rwanda (1994), Afghanistan (2001) and Iraq (2003). In their deployment to Iraq, Prime Minister Koizumi forced legislation through the Diet that paved the way for 1000 Japanese troops to be deployed in a US-led occupying army trying to quell a guerilla war, even though they were supposed to undertake "non-combat" duties in "safe-areas." In short, Japan's intervention in the Middle East has therefore increasingly taken on a military nature (Wagner and Cafiero 2014). From the deployment of minesweepers to the dispatching of troops piggybacking on the US or UN missions, Japan has shown an increasing propensity to deploy military force to achieve its goals.

This chapter highlights this important aspect of Japan's normalization and rejuvenation vis-à-vis its deployment of its naval assets to fight piracy. Remilitarization remains one of the obvious hallmarks of Japan's normalization and rejuvenation. In dispatching military forces, Japan's neoconservatives continually erode or sidestep its constitutional constraints. The deployment of Japanese forces to the Gulf of Aden to fight piracy is marketed under the auspices of assisting the US in their military operations. The importance of this "assistance" is presented to domestic audiences in Japan as one of fulfilling Japan's treaty responsibilities, participating in the provision of an international public good, thus fulfilling Japan's international obligations. It allows Japan to stifle accusations of a freeriding Japan and enables the US to justify and continue its alliance in face of the difficulties both at home and in Japan. More importantly, it provides an opportunity for Japan's MSDF to gain more experience of blue- 
water naval operations, and allows for an opportunity for the international community to be socialized into seeing a Japan that can operate far from its shores. The same act of deployment essentially carries a coded message to all actors in and outside the region that Japan is indeed a rejuvenated global power.

Japan's foray to provide the international good of keeping piracy at bay also stimulated developments on the Chinese side. As elaborated in Chap. 2, Japan's identity and ambition is not just anchored by the US-Japan security alliance, it is also heavily referenced by China. Prime Minister Abe has clearly and unequivocally stated that Japan's foreign policy is not all about China. If this is the case, there should not be the need to mention this at all. The fact of the matter is that one of Japan's main concerns in foreign relations over the last two centuries, not decades, has been about China, whose ascendance has buoyed and worried Asian states, Japan included, in numerous ways. As a colleague commented to the author recently, "it's like living next to an elephant-what it does affects and worries you in so many ways-even when it snores." When it comes to Japan, this is doubly true, given Japan's antagonism with China over so many issues, ranging from the arguments over the ideational, for example, whether Japanese politicians have a right to worship at Yasukuni, to the contestation of the Senkaku Islands, to gas deposits in the East China Sea-one of the prime reasons, or perhaps the excuse, that drives Japan's normalization efforts. This understandably so, as throughout the Cold War, the US and its allies have been accustomed to a huge strategic capability gap between themselves and China, and that chasm is now closing and closing fast.

Japan's attempt at rejuvenating itself politically is not without cost. The first cost is apparent - the alliance is not cheap to maintain, much less enhance. Japan is now showing signs of recovery from years of economic stagnation. Both the US and Japan face opposition at home from time to time, throwing into question the veracity and usefulness of this alliance. General Tamogami, one of Japan's retired generals, favored Japan's alliance with the US, but questioned openly whether the US could be counted on to defend Japan in a conflict against China (Halloran 2011). In Japan, the opposition in Okinawa is particularly jarring, and raises the extent of Japan's democratic credentials (McCormack and Norimatsu 2012). Justified on the grounds of national security, most Japanese living outside of Okinawa are of the view that it is even more necessary, given the rough neighborhood they live in. Facing a belligerent North Korea, an equally nationalistic South Korea and worst of all, a resurgent irredentist China, 
the Japanese public is almost persuaded that it is necessary to "confront" China. The US in fact has to do very little these days to persuade Japan of the merits of the US-Japan security alliance. Likewise, it would be sacrilegious in Japan to suggest that all this chest thumping has gone slightly overboard, but it would be prudent to put forth this reminder for the Japanese politicians: The US makes foreign policy to enhance US national interests first and foremost, and Japanese interests never take precedence. In truth, Japan's interests cannot be guaranteed by the US-Japan alliance alone, and many Japanese policymakers know this.

Japan's rejuvenation as a global power largely began in the 1980s as its economic clout grew. Despite this, Tokyo has been extremely circumscribed in its foreign policy arsenal-as certainly by the country's very narrow interpretation of Article 9 of its constitution, the constraints of pacifist culture and anti-militaristic norms that had so engrained in the country's strategic culture.

This chapter argues that one small step forward in this relationship is perhaps for China and Japan to show that it is not implausible that they could work together. In this case, Japan and China working in the Gulf of Aden should be lauded as one of the more successful multilateral collaborations, in particular to domestic audiences in both China and Japan, so that the public sentiments necessary for building better relations could be established. There must be political will to do this very successfully of course in the domestic media, but unfortunately to date there have been few reports on this. However, this does not preclude scholarly endeavors to identify and explore this as a possible front or opening for Sino-Japanese cooperation.

The provision of international public goods-for example, helping bring pipe water to isolated parts of Africa and Latin America or cosponsoring poverty alleviation or health projects-might be options for China and Japan to build more confidence in their partnerships and at the same time enable them to achieve their great power aspirations. Instead of focusing their energy on competitive endeavors to fight for territorial possessions or resources in the East China Sea, these projects could actually be good for Sino-Japanese relations in the long run. East Asia can only become harmonious if, and only if, China and Japan consider the stakes more carefully. This chapter shows that Japan's cooperation with China in combating piracy in the Gulf of Aden is a small but important development, holding much significance for both theoretical and empirical studies on Japan's foreign relations. 


\section{Genesis of Japan's Anti-Piracy Efforts}

According to current international law, the act of piracy as defined in Article 101 of the 1982 United Nations Convention on the Law of the Sea (UNCLOS) consists of the following acts:

1) any illegal acts of violence or detention, or any act of depredation, committed for private ends by the crew or the passengers of a private ship or a private aircraft, and directed -

(a) on the high seas, against another ship or aircraft, or against persons or property of any State;

(b) against a ship, aircraft, persons or property in a place outside the jurisdiction of any State;

2) any act of voluntary participation in the operation of a ship or of an aircraft with knowledge of facts making it a pirate ship or aircraft;

3 ) any act of inciting or of intentionally facilitating an act described in subparagraph (1) or (2).

The UNCLOS definition constrains the acts of piracy to the "high seas" and "outside the jurisdiction of any state," essentially stating that the acts of piracy cannot take place within the sovereign boundaries of any nation-state. The International Maritime Bureau (IMB) has, in turn, adopted a more liberal definition, defining piracy as "an act of boarding or attempting to board any ship with the intent to commit theft or any other crime and with the intent or capability to use force in the furtherance of that act" (Ece 2012: 12). This definition includes acts occurring in territorial waters of states, but it separates conceptually cases whereby the hijacking of crafts might not be for private ends (i.e. not for profit or monetary reasons, but say for politically motivated goals). Terrorism would, therefore, be included in this definition. The IMB definition, however, is used more for reporting, and technically, the UNCLOS definition is still for all intents and purposes the primary definition adopted for piracy.

Historically, all countries in Asia, including Japan, have had to grapple with this issue within the region. The root of the "modern" piracy problem began in the 1990s with a series of hijackings in the Straits of Malacca and the South China Sea (Beckman et al. 1994). Japan saw a series of attacks on its shipping, which prompted a reconsideration of its maritime policies and 
its general security policies concerning piracy as some of the incidents were particularly troubling. In 1992, the hijacking of the Nagasaki Spirit, which collided with another vessel, caused an oil spill of over 100,000 tons of oil, which in turn started a massive fire that ultimately killed 44 sailors (Fort 2006: 34-36; Burnett 2003). There were other ships that were hijacked or attacked: the Tenyu (1998), the Odyssey Rainbow (1999), the Global Mars (2000) and the Arbey Jaya (2001).

These attacks occurred primarily (Beckman et al. 1994) in the vicinity of the Straits of Malacca, prompting Tokyo to focus its initial anti-piracy efforts in Southeast Asia. Until then, piracy had never been construed as a fundamental problem for Japan and Japanese security.

Due to the direct threat to its shipping, piracy was, for the first time in the postwar era, construed as a threat to Japan's comprehensive national security in the postwar period. Japan imports almost all its petroleum needs, over $70 \%$ of its food sources, and in turn ships over $90 \%$ of its exports globally. The series of incidents in the South China Sea sparked off a debate within Japan and propelled this to become one of the most important items on the government's agenda. Beyond the question of crafting a response to the perceived threat to its comprehensive national security, there have been calls for Tokyo to build up a more coherent global strategy (Watanabe 2007: 160-167). Within Japan, domestic actors also had a vested interest in urging the government to formulate a more coherent response. In particular, both the Japan Defense Agency and the Japan Coast Guard (Takeda 2004: 47-50) were keen to play a greater institutional role in helping enhance sea-lane safety and preventing ships from being hijacked. The singular focus of attention from the Japanese government, legislators, Defense Agency, Coast Guard and other interest groups pushed Japan to overcome decades of inertia. ${ }^{1}$

The impetus to "normalize" Japan became stronger from the mid1990s onwards. This stemmed from a series of external "jolts": the loss of the USSR as a strategic threat, the international reactions to Japan's perceived checkbook diplomacy (especially in the wake of the Gulf War that liberated Kuwait); and more importantly, the evolution of a new generation of Japanese who perceived the constraints imposed by the legacies of the Pacific War as an unnecessary burden on Japan's gaining of its rightful

\footnotetext{
${ }^{1}$ It has been argued that a constructivist approach should be used to view Japan's intervention in the Gulf of Aden, in particular the debate on the responsibilities between the Japanese Coast Guard and the MSDF demonstrates the continuing resilience of the normative force of Japan's pacifist identity (see Black 2012: 259-285).
} 
status and respect in the international community. Since the mid-1990s, a series of Japanese prime ministers with relatively conservative views- the likes of Ryutaro Hashimoto, Junichiro Koizumi, Shinzo Abe and Taro Aso-have been steering the country on a right-of-center political agenda. As a vehicle of the normalization agenda, Japan has been keen to dispatch naval vessels to areas outside the Japanese navy's traditional zone of operations. Consequently, Japan strove to reach out to Southeast Asian states to cooperate on this problem. Japan's overtures were a mixed bag of successes, with countries such as Singapore, Malaysia and Indonesia reacting differently (Bradford 2004: 480-505). By the early 2000s, with the rise of domestic voices calling for a rethinking of the role Japan was playing in global affairs, the Japanese government was extremely keen to demonstrate its "normality" by dispatching troops to the Middle East.

Japan supported the Regional Maritime Security Initiative (RMSI) proposed by the US in 2004. However, some ASEAN states such as Malaysia and Indonesia-littoral states adjacent to the Straits of Malacca-were apprehensive about US-led efforts here. There was of course resistance from China, which was eager to avoid discussing a possible US-led presence in the area known as the Hong Kong-Luzon-Hainan triangle, and at the same time, regional cooperation had been and continued to be, hindered by territorial disputes between China, the Philippines and Vietnam (Chan et al. 2012: 170). Nonetheless, with regards to the sensitivity of its presence in the South China Sea (at least before tensions with Vietnam and the Philippines increased over the last few years over the Spratly Islands), China appeared to be happy to leave the heavy lifting of fighting the pirates to Malaysia, Indonesia and Singapore. The ASEAN states were able to come together to take active measures on a unilateral or multilateral basis to contain the situation. Owing to the War on Terror, there were a slew of successful initiatives such as the Department of Homeland Security's Container Security Initiative (CSI) ${ }^{2}$ the Regional Co-operation Agreement on Combating Piracy and Armed Robbery against Ships in Asia (ReCAAP), and the Proliferation Security Initiative (PSI), but by and large these initiatives did not receive much attention from China.

Japan's dispatching of MSDF personnel to partake in the safeguarding of vessels passing through the Gulf of Aden is a remarkable departure from previous Japanese policy in a variety of ways. First, this was the first time

\footnotetext{
${ }^{2}$ Singapore, Malaysia, Hong Kong, South Korea and China are some of the countries participating in this US initiative.
} 
that Japan had dispatched its maritime forces to the Middle East for an actual operation. Second, this was an independent deployment for antipiracy missions in the Gulf of Aden, to safeguard Japan's own interests. Third, even though Japan was seizing the opportunity to deploy its navy on a far-flung mission and work in a multilateral setting, it also marked a first as Tokyo was also trying to match the Chinese in terms of such a deployment. Even though this began as some sort of "competition," as the following chapter will explain, the Japanese and the Chinese taskforces eventually came together to collaborate on the mission at hand. Their efforts to cooperate began under a multilateral setting, underscoring that it is entirely possible for the two Asian giants to come together to cooperate strategically.

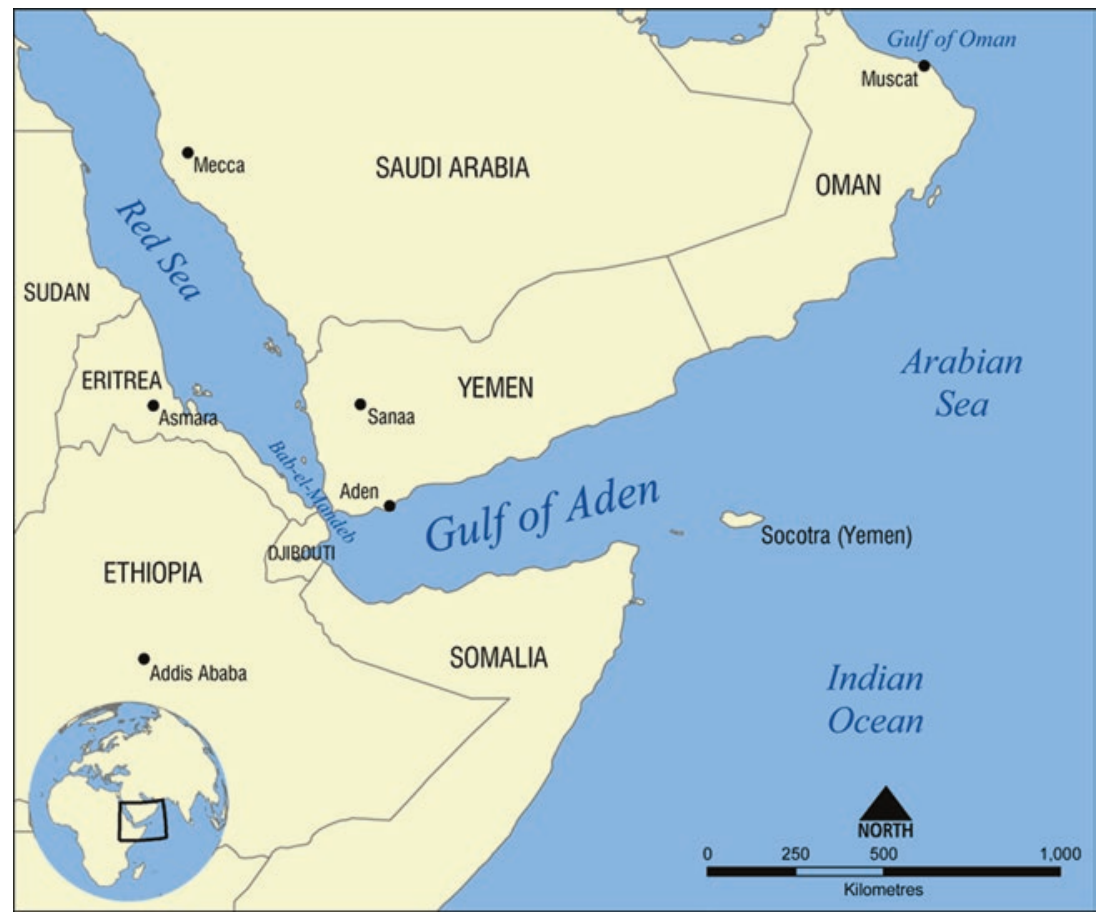

The Gulf of Aden. (Map showing the Gulf of Aden, located between Yemen and Somalia. Nearby bodies of water include the Indian Ocean, Red Sea, Arabian Sea and the Bab-el-Mandeb Strait. By Norman Einstein (Own work) [CC BY-SA 3.0 (http://creativecommons.org/licenses/by-sa/3.0) or GFDL (http://www.gnu. org/copyleft/fdl. html)], via Wikimedia Commons) 


\section{Piracy in the Gulf of Aden: An Overview}

The Gulf of Aden is strategically located between Yemen on the southern coast of the Arabian Peninsula and Somalia, in the northern part of the Horn of Africa. The Gulf's importance is derived from the fact that the waterway is part of the Suez Canal shipping route between the Mediterranean and the Arabian Seas in the Indian Ocean with 21,000 ships crossing annually. The Gulf of Aden is also closely located to another critical chokepoint in the world: the Straits of Hormuz, which lie between Oman and Iran. The US government estimated that there was a flow of about 17 million barrels per day, up from 15.7 to 15.9 million barrels per day in 2001 (Komiss and Huntzinger 2011: 1). In 2011, 20\% of the world's traded oil, with more than $85 \%$ of the crude oil exports, went to Asian markets, with Japan, India, South Korea and China as the largest destinations (United States Energy Information Administration 2012). The Gulf of Aden and the Straits of Hormuz are therefore extremely important areas of interest for China and Japan. Beyond the question of trade flows, a significant amount of petroleum-based imports destined for Northeast Asia transit through the Gulf. As the demand for transnational shipments between East Asia and the Middle East grows, the security of the sea-lanes and lines of communication in the Gulf of Aden become increasingly important.

The growth of piracy as an "industry" in the area can be traced back to the failure of the Somali state in the early 1990s. Ravaged by a civil war that was fought following the collapse of the ruling government in 1991, Somalia lapsed into anarchy characterized by clan-based rivalry and militia groups competing to control the national infrastructure (World Bank Report on Conflict in Somalia 2005). With the demise of the central government and the disbanding of state institutions such as the navy and the merchant fleet, foreign vessels allegedly engaged in toxic dumping activities and illegal fishing in Somali waters. (Ironically, there were reports that among those vessels engaged in illegal fishing, some belonged to Taiwanese fishermen who were fishing for tuna in Somali waters, and in turn their catches were being sold to the fish markets in Japan.) Captured Somalis engaged in piracy not only out of survival and desperation, but also to defend Somalia against these illegal activities, estimated to cost Somalia USD 100 million a year (Fox \& AP, 25 July, 2013). In fact, among the Somalis, the pirates call themselves "saviors of the seas." The illegal fishing boats reportedly came from Yemen, Iran, Taiwan and Korea, among others. 
The pirates' modus operandi is often to use single or multiple small but extremely agile speedboats to approach by stealth and board the larger merchant ships, using a combination of ropes with hooks and climbing up via the anchor chain, then hijacking the crew at gunpoint and steering the ship to one of their hideouts. There have also been instances where the pirates have used guile to commit their crimes, often pretending to be stranded fishermen asking for water, only to board and hijack the merchant ships (Westcott 2008). The pirates were also known to have launched rocket missiles to fire warning shots across the bows of fleeing ships to stop them (Walker 2009).

The economic costs to merchant fleets worldwide are tremendous. If ships were to avoid the pirate-infested waters off Somalia, there would be exponential costs to the shipping. For example, routing a cargo ship from Europe to the Far East via the Cape of Good Hope, rather than through the Suez Canal, would incur an estimated additional USD 89 million annually, which includes USD 74.4 million in fuel and USD 14.6 million in charter expenses. In addition, the rerouting would increase transit times by about 5.7 days per ship. This would result in the need for an additional vessel to maintain the service frequency. Additionally, these costs do not consider the disruption in logistics chains (United States Department of Transport 2010). For every USD 120 million seized by pirates in Somalia, the cost to the shipping industry and end-users is between USD 0.9 and USD 3.3 billion (Besley et al. 2012). The piracy industry grew partly because it was much cheaper and easier for ship owners to pay off the ransom to get back their ships than it was for them to try and pressure their respective governments to "retrieve" the ships. The two-year old Greek tanker, MV Smyrni, loaded with crude oil worth millions of dollars, was released after 11 -month negotiations and a payment of around USD 15 million. (The Guardian, May 3, 2013).

Between 2005 and 2012, the number of hijackings increased exponentially, with 179 ships hijacked off the coast of Somalia and the Horn of Africa. Figures from the IMB indicate a similar pattern of increase, particularly from 2009 onwards. In 2009 alone, there were 46 ships hijacked, in 2010 there were 47 , and by 2011 , there were 25 successful hijackings out of 237 attempts. In 2012, there were only 14 successful hijackings out of 75 reported attacks (The Guardian, May 3, 2013). Statistics from the International Chamber of Commerce showed similar results. As of September 2012, there were 13 hijackings reported with 212 hostages 
taken, with 11 ships and 188 hostages still being held in Somalia at the time of reporting (International Chamber of Commerce n.d.).

According to the International Criminal Police Organization, the United Nations Office on Drugs and Crime and the World Bank, ransom payments to Somali pirates are estimated to have been between USD 339 million and USD 413 million for the same period. The average ransom paid was USD 2.7 million, with ordinary pirates receiving USD 30,000 to USD 75,000 each and bonuses paid to those who brought their own weapons or were first to board the ship (Harress 2013). This constitutes an "industry" because the pirates who carry out the actually hijacking get a relatively small portion of the ransom, with the "investors" (the warlords or the businessmen who invested in the equipment and the upkeep of the hostages) getting the lion's share of the ransom.

The case for concerted international intervention appears to therefore have been confined to a period of roughly eight years, from approximately 2005 to 2012 . The sudden and sharp increase in piracy cases was prompted by both a lag in the international legal infrastructure and the inability of international governments to combat the piracy problem. As the efforts of the international community to combat the scourge came to bear, the number of cases reduced abruptly from 2013 onwards. In particular, the multilateral task forces with their lethal firepower and successful prosecutions with lengthy prison terms for the pirates meant that the costs were escalating for those involved in piracy. The section below will discuss in detail the evolution of the changes in international law, and contextualize Japan's efforts in this change.

\section{International Law and the Piracy Problem}

The UNCLOS of 1982 (LOS Convention), stipulates that the extent of a state's territorial waters is confined to the region within 12 nautical miles of its coastline. The convention also recognizes the Exclusive Economic Zone (EEZ) of 200 nautical miles, whereby the state has special rights in terms of exploration and mineral rights. In particular, Article 58(3) of the convention stipulates that states shall have "due regard to the rights and duties of the coastal State and shall comply with the laws and regulations adopted by the coastal State in accordance with the provisions of this Convention and other rules of international law in so far as they are not incompatible with this Part." 
This confers both a privilege and a burden on coastal states. Piracy in the traditional sense of the word could be construed as "armed robbery" in the territorial waters of the states, and for most part, it is the duty of the coastal state to ensure that such crimes are not committed in their territorial waters. Many states, in particular those without the capacity to enforce laws, have a hard time meeting these obligations insofar as piracy is concerned.

Thus, prior to 2008, the inapplicability of international law of piracy in territorial seas posed a problem in combating piracy in the Gulf of Aden. The international law accorded the Somali pirates a measure of safety, as the customary and conventional law of piracy provided that piracy could only occur on the high seas and not in areas subject to state sovereignty (Convention on the High Seas 1958; Convention on the Territorial Sea and Contiguous Zone 1958). Additionally, on the high seas, it is generally accepted that the flag state has jurisdiction over the vessels flying its flag, and may not be boarded, searched or molested by foreign flag vessels without the consent of the flag state, with the only possible exception being when the vessel(s) involved are linked to piracy. Thus, under modern international law, ships or vessels originating from Somalia related to piracy and pirates can be seized, arrested and prosecuted by other states or authorities (United Nations Convention of the Law of the Sea 1982).

The situation with piracy thus increased exponentially in the Gulf of Aden because of a mixture of circumstances-the failure of the Somali state, the inability of international law to deal with the situation, and most importantly the lack of protection accorded to the commercial fleet plying these treacherous waters. What started as a string of isolated incidents in the early 2000s had by 2008 developed into a mature business model, posing a significant threat to the busy shipping lanes near Somalia to the extent that the UN secretary-general and the Security Council requested international assistance to escort vulnerable World Food Programme (WFP) vessels (Hopkins and Swarttouw 2014).

The Security Council adopted Resolution 1816 in 2008 to overcome this difficulty and subsequently the mandate was renewed through resolutions 1846, 1897, 1950 and 2020 (Security Council 2010). Resolution 1816 authorized countries concerned to enter the territorial waters of Somalia and use "all necessary means" to repress acts of piracy and armed robbery at sea (UN 2008a). Additionally, the UN Security Council has also established various mechanisms to deal with the piracy problem in Somalia; Resolution 1846 endorses the seizing of vessels in Somalia territorial waters associated with piracy (UN 2008b); Resolution 1851 (Text of Resolution 1851) 
called for the cooperation of states with the transitional federal government in Somalia to include potential operations in Somali territorial land and airspace, to suppress acts of piracy and armed robbery at sea. The resolution also urged "countries to establish an international cooperation mechanism as a common point of contact for counter-piracy activities near Somalia, and to efforts to enhance the judicial capacity of regional states to combat piracy, including the judicial capacity to prosecute pirates." In 2009, the Contact Group on Piracy off the Coast of Somalia (CGPCS) was therefore established with 24 countries, including Japan, the US, China and nine other international organizations in Japan at the United Nations headquarters (Contact Group on Piracy 2009, 2015). At the meeting, the Contact Group delineated six areas of discussion and focus: (i) improve operational and informational support to counter-piracy operations; (ii) establish a counter-piracy coordination mechanism; (iii) strengthen judicial frameworks for arrest, prosecution and detention of pirates; (iv) strengthen commercial shipping self-awareness and other capabilities; (v) pursue improved diplomatic and public information efforts; and (vi) track financial flows related to piracy (Contact Group on Piracy 2015).

Resolution 1918 called on "all States, including States in the region to criminalize piracy under their domestic law and favourably consider the prosecution of suspected and imprisonment of convicted pirates apprehended off the coast of Somalia, consistent with applicable international human rights law." UN Resolution 1976 called for the creation of specialized courts to prosecute and house Somali pirates, as well as for laws to be created in their own national jurisdictions so that pirates could be prosecuted. UN Resolution 1897 encourages states to "conclude special agreements or arrangements with countries willing to take custody of pirates. Those arrangements should allow for the embarkation of law enforcement officials-or 'shipriders'-from these willing countries to facilitate the investigation and prosecution of persons detained as a result of anti-piracy operations, provided that the advance consent of the TFG was obtained for third State jurisdiction in Somali territorial waters and that such arrangements did not prejudice the effective implementation of the 1988 Convention for the Suppression of Unlawful Acts against the Safety of Maritime Navigation" (UNSC 2010). One of the most significant outcomes was that since 2009 , any pirates captured by international naval forces are handed over to Kenya for trial. Effectively, from 2008 right through to 2011 , no less than ten resolutions were passed to encourage third state intervention in Somali territorial waters (United Nations Security Council Resolutions 2012). 
Japan had little experience operating in the Gulf, but the exigencies of the piracy challenge gave each power the reasons to consider deploying to the Gulf. This problem provided these Asian giants with an opportunity to join the multilateral movement, proving that cooperation as opposed to competition in strategic realms between China and Japan is entirely possible under the right conditions.

\section{Japan’s Response to the Piracy Problems in the Gulf}

Even though Japan's anti-piracy efforts stemmed from a genuine need to protect its commercial shipping, its efforts cannot be divorced from its larger diplomatic and security strategy. Japan's operations in the Gulf of Aden could be construed as a larger part of Japan's interest in expanding its influence and prestige in Africa and the Middle East. Conducting naval operations in the name of providing a public good in an area outside their traditional area of influence would provide excellent opportunities for Japan, ${ }^{3}$ and also other countries such as China (Kaufman 2009), to gain a foothold in the affairs of the region and familiarize themselves with the regional actors. To be sure, such gestures in so quickly dispatching naval deployments might also have been prompted by what another country was doing - such as Japan and China competing to be a global power prompted by nationalistic impulsesbut this was something to be expected. Furthermore, their involvement in the provision of public goods (anti-piracy) is also an extremely important indicator of their great power aspirations, as it indicates a readiness to perform international public services. The willingness to participate, serve and lead on these global platforms also enables Japan to socialize other powers (such as China) to their presence, and if anything, allows them to garner capital for their global leadership credentials. Japan's deployment also cannot be divorced from Japanese observations of what China is doing in the region, as the government's response is meant to ensure that Japanese efforts and capabilities are "matched up" to her close neighbor's.

Even though the Chinese economy grows from strength to strength, China's foreign policy is still relatively reactive and conservative. China still largely does not attempt to exercise leadership in international affairs, particularly in situations where the use of force is required, as Beijing

\footnotetext{
${ }^{3}$ For a detailed survey of the activities undertaken by Japan, please see the Japan Ministry of Defense website on "Measures Against Piracy", http://www.mod.go.jp/e/d_act/somalia/index.html; see also the pamphlet "Counter Piracy Initiatives," Japan Ministry of Defense, http://www.mod.go.jp/e/publ/w_paper/pdf/2013/39_Part3_Chapter2_Sec3.pdf
} 
adheres to the doctrine of non-intervention in the affairs of others and has always held the sanctity of sovereignty in high regard. In this instance, the situation with Somalia and the UN resolutions that were passed paved the political context for China's deployment to the Gulf (LinGreenberg 2010).

In 2008, China initiated the first escort mission for its merchant ships to Somalia. The first escort mission was prompted by two incidents that had occurred just prior to the Chinese deployment (People's Daily, December 29, 2009a). The most widely advertised incident involved a Chinese cargo merchant ship, the Zhenhua 4, which was almost captured by the Somali pirates on December 17,2008. The incident was widely and graphically covered by the Chinese state and social media when the Shanghai head office of the shipping company provided photographs transmitted by the Zhenhua 4's crew to them (QQ News, January 22, 2009). ${ }^{4}$ The Chinese foreign ministry subsequently announced that it would extend the escort missions to Hong Kong, Macanese and Taiwanese ships, with 15 merchant ships applying for escort within four days of the scheme being announced on January 6, 2009 (People's Daily, January 6, 2009 b). The independent nature of China's deployment was made adequately clear: the deployment was not to accept any assignments or instructions from any other countries or regional organizations. This also registers one of the first times that the modern People's Liberal Army's navy (PLAN) sent an expeditionary force abroad (Weitz 2009).

The initial escort mission consisted of three ships. The flagship was a DDG-169 Wuhan (Guangzhou-class) multi-purpose missile destroyer built in Shanghai in 2002, with a displacement of 7000 tons, equipped with 16 anti-ship missiles, 48 surface-to-air missiles, close-in weapons systems and a helicopter. It was accompanied by a DDG-171 Haikou, the

\footnotetext{
${ }^{4}$ Photographs of the abovementioned encounter with the pirates were taken by a crew member named Wu Mingxiang on the Chinese vessel Zhenhua 4, while it was in the process of being hijacked. One of the photos showed the crew defending themselves against the pirates with Molotov cocktails, drawing intense public attention to the piracy issue. The pictures and videos were transmitted to the shipping company's headquarters and the images were transmitted widely to the media. See "The Story Behind the Merchant Ship's Successful Defence against the Somalian Pirates", QQ News, January 22, 2009, http://news.qq. com/a/20090122/000727.htm; more pictures can be found in the Xinhua News Agency article, "Yading Wan Tou Tufei Ji" ["Fighting the Pirates in Aden"] 2015, http://www. china.com.cn/news/txt/2008-12/19/content_16974634.htm. The CCTV clip of this episode can be viewed here: "Zhonguo chuanyuan yong zijiranshaodan jitui suomali haidao," YouTube, https://www.youtube.com/watch?v=Mnq4NrR4-V8
} 
PLAN's latest Lanzhou-class destroyer completed in 2003. The Haikou destroyer is equipped with China's first generation of phased-array radar and vertically launched long-range air defense missile systems, providing air defense to the fleet. Both ships were supplied by the Weishanhu, a PLAN Qiandaohu-class supply ship. The Weishanhu is an indigenous multi-product replenishment ship and can take part in offensive operations using its eight $37 \mathrm{~mm}$ guns (People's Daily, December 27, 2008). In addition, the destroyers are equipped with Russian-built Kamov Ka-28 helicopters, greatly expanding the surveillance and response coverage of the destroyers (editorial - Naval Technology n.d.). In the initial deployments, China's naval tasks were principally "escort" missions, as opposed to a more permanent presence in the region (America's Navy 2009).

Japan's presence was to work with the UN and the US deployment. The combined Task Force 150 (TF150) is a task force formed out of the 25-nation Maritime Task Force operating out of Manama, Bahrain. Commissioned in 2002, the initial aim of the Maritime Task Force is to participate in and support the Global War on Terror, with the primary task of mounting maritime security operations around the Horn of Africa region and the Indian Ocean. For example, between 2006 and 2008, the TF150 conducted operations to interdict vessels and personnel associated with piracy off the coast of Somalia. In 2009, a new combined task force, TF151, was established to focus on combating piracy in the region. Its mission was to disrupt piracy and armed robbery at sea and to engage with regional and other partners to build the capacity and improve relevant capabilities to protect and enhance the freedom of navigation. TF150, and subsequently TF151, were naval coalitions of the US and its allies, established to respond to "distress calls" or mission orders from the coalition (China was not involved initially in the maritime security operations mounted by the US-led Combined Maritime Forces), NATO's Operation Enduring Freedom or the EU's Operation Atalanta-all three acted as the main forces operating in the region.

By 2010, China had lobbied for an increased role in the international fight against piracy and had agreed to participate and co-chair Shared Awareness and Deconfliction (SHADE) meetings, to share in planning joint operations for TF151, as well as sharing intelligence with the other task forces (BBC, January 29, 2010). It must be emphasized that even though China sought to work more closely with the international task force, its participation was still on a voluntary basis, as Beijing had been careful to ensure that Chinese forces did not get incorporated into a com- 
mand structure outside the Chinese chain of command-in particular TF151, Operation Atalanta and Operation Enduring Freedom.

By the end of 2013, 16 Chinese task forces (comprising three ships each) had been sent consecutively to the Gulf of Aden since China had first started the deployments on December 26, 2008. These ships account for almost half of the latest Chinese destroyers, frigates and replenishment ships from the three PLAN fleets. The Chinese task forces had escorted 5460 ships, including 2765 foreign ships. Additionally, they also escorted seven ships of the WFP in cooperation with the EU CTF-465 (Zhou 2013).

Japan's journey toward their piracy efforts in the Gulf (Sakurai 2013) was undertaken on a radically different and difficult route (Japan MOD Fight Against Piracy website 2009). Prior to 2009, Japan's ability to protect merchant naval assets on the high seas was constrained by its domestic laws. There was no special law to deter piracy on the high seas, and any action undertaken by the Japanese authorities was only legal if the ships involved were Japanese (defined as Japanese flagged ships and foreign ships with Japanese crews). Operating under Article 82 of the Self Defense Force Law, this meant that JSDF ships were also hampered in their operational tactics in their engagement with the pirates, as well as the handling of captured pirates as part of "maritime security operations." From March 2009 onwards, the Japanese MSDF deployed two destroyers and two P-3C aircraft for surveillance activities. The Japanese deployment was initially headquartered in the US Army Camp Lemonnier, south of Djibouti airport. The destroyers were DD Sazanami and DD Samidare of the MSDF, both of which are among the MSDF's most capable naval assets. The two destroyers have a complement of about 400 officers with eight officers of the Japanese Coast Guard sailing along as judicial police officers. In dispatching the P-3C patrol and surveillance planes, alongside the helicopters on the destroyers, the MSDF proved to be extremely effective in counter-piracy operations (Japan Ministry of Defense 2009a, b). The operational efficiency of the Japanese deployment was remarkably enhanced after the passage of the "Anti-Piracy Law," which allowed the Japanese forces to escort foreign commercial ships and also engage (i.e. fire at) pirate vessels if they ignored warning signals.

From June 2011, Japan was able to conduct anti-piracy efforts from a new base, built north of the airport, which also served as the local coordination facility. This facility was built at a cost of JPY 4.7 billion, and would house the headquarters building, dormitories, a P-3C patrol plane 
maintenance hangar, and a gymnasium for MSDF members. The MSDF had previously moved from the US military base located to the south of the airport (The Somaliland Times, June 4, 2011). By 2014, Japan had conducted 567 escort measures under its anti-piracy laws, and had escorted 3469 merchant vessels in total (Japan Ministry of Defense 2013, 2014; US Department of Homeland Security 2014).

Japan's involvement in the anti-piracy campaign fitted remarkably well with the prevailing political ambitions of the neo-conservative government's plans, the exigencies of Japan's attempt at the normalization of Japan's presence, as well as the conditions required of and for the strengthening of the US-Japan alliance. Even though it was largely the Aso administration that started the initiatives associated with the dispatch of the naval assets, it was the DPJ governments (from September 2009 onwards) that pushed for these deployments. This is despite the fact that Prime Minister Yukio Hatoyama had very different ideas about what Japan's relations with its neighbors should be like vis-à-vis the US.

\section{Working With the Chinese PLAN \\ and the Multilateral Provision of International Public Goods}

Even though Japan had therefore come to the Gulf of Aden under very different circumstances, this coincidence of events resulted in some happy circumstances. Japan had initially entered the region under the auspices of supporting the US in the Global War on Terror, but subsequently moved to the anti-piracy missions. The UN Security Council resolutions and the anti-piracy law passed in 2009 in Japan provided the legitimacy and the flexibility needed for Japan to integrate their efforts more closely with other navies in the region. The Chinese naval forces were dispatched owing to the exigencies of circumstances and the call for the UN Security Council to combat the pirates. Yet, as the number of piracy attempts increased from 2008 onwards, it was evident that many other countries had become concerned enough with the situation to dispatch naval assets to that area to help in this effort. India, Singapore, South Korea, Pakistan, the Philippines and even Iran had dispatched naval assets to the Gulf for anti-piracy missions. As most of the naval task forces in the region were led by either the US or EU, many countries, including China and India, established independent mandated missions from these "presence" groups, for political as well as operational reasons. 
The instrument that facilitated the Japanese forces to come into contact and work with the Chinese ironically was a multilateral forum initiated by the coalition task force. The SHADE forum was reportedly established in December 2008 as a means of sharing "best practice," conducting informal discussions and deconflicting the activities of those nations and organizations involved in military counter-piracy operations in the region. This forum is organized at the officer level, and initially only involved those forces based in Bahrain, but it grew to include the forces operating with independent mandates, such as Japan, China, Russia and India. It is important to note that this was a "bottom-up" process, rather than one willed from the top.

One of the most under-rated and undiscussed implications of SHADE is the coming together of Japan's deployment forces with the Chinese in this multilateral setting. Facilitated by SHADE, Chinese and Japanese forces worked together with other navies to enhance the mission objectives. This formal cooperation between China and Japan (and South Korea joining subsequently) in the anti-piracy efforts began in 2012, when together with India they formed the Joint Escort Convey Coordination group (CNN 2011). Also, under the auspices of SHADE, the Japanese MSDF agreed to share information on their warship movements and relevant intelligence on piracy (Gokhale 2012). This arrangement occurred from January 12012 onwards (The Economic Times, February 1, 2012). Likewise, the Chinese deployment forces made reciprocal arrangements.

This was the first time that the Japanese military forces had worked closely with the Chinese. As stipulated in China's white paper in 2013, the Chinese navy was the reference navy for the first round of coordination in 2012. Together with India and Japan, they harmonized their maritime assets' patrol schedules on a quarterly basis, and were able to optimize the available ships on duty, enhancing escort efficiency (State Council of China 2013). South Korea joined this coordination in the last quarter of 2012 , just a year after mounting an impressive and daring rescue operation code-named "Dawn of Gulf of Aden" (Roehrig 2015). Compared with the preceding years, when all the navies with independent mandates worked separately, this was a significant improvement. The most important aspect of this cooperation was the fact that China and Japan (and by extension, India and South Korea) were able to work jointly together, and were able to change the leadership of this loosely formed group on a rotational basis. They were even able to organize mutual exchanges and other social events. 


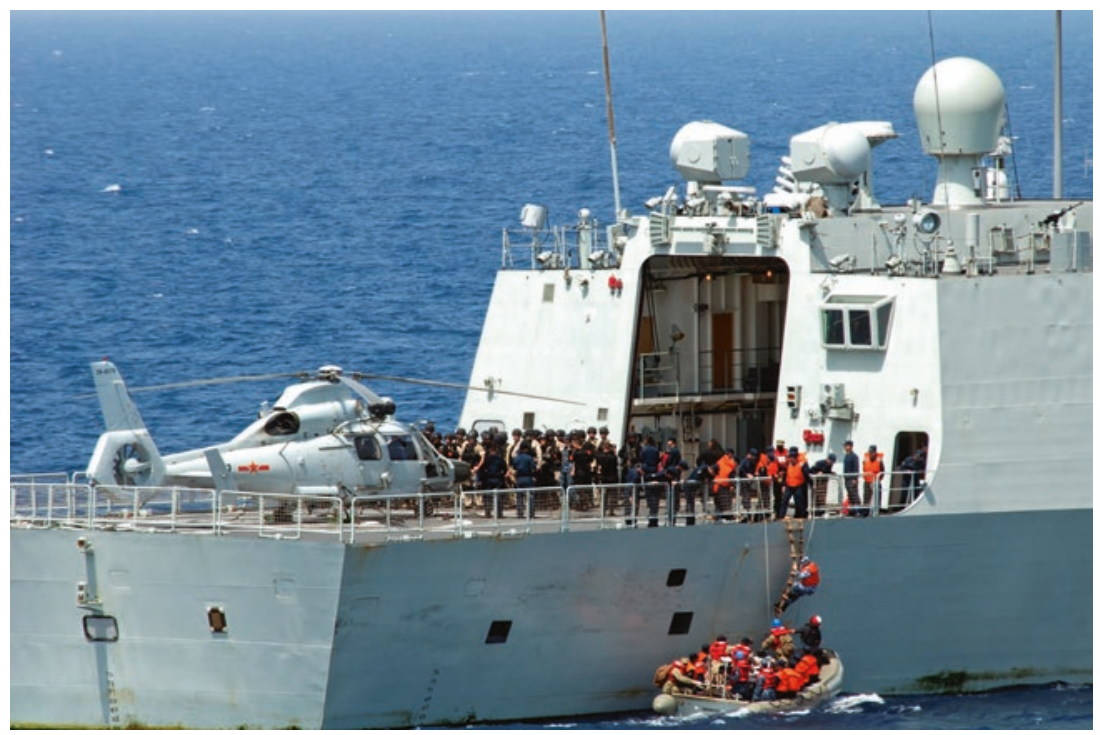

Sailors visiting the Chinese navy frigate Yang Yi in Gulf of Aden in 2012. (Sailors from the guided-missile destroyer USS Winston S. Churchill (DDG 81) board the PLAN frigate Yi Yang (FF 548) to meet on Monday, September 17, 2012, prior to conducting a bilateral counter-piracy exercise in the Gulf of Aden. (Copyright held by: US Navy. Photo by mass communication specialist 2nd Class Aaron Chase/ Released on Flickr) 120,917-N-YF306-107; made available by a Creative Commons License Attribution 2.0 Generic license)

This cooperation between the navies was not promoted widely in Japan's or China's domestic media and public narratives. The domestic media in both countries only focused on the achievements of their respective maritime forces in undertaking anti-piracy missions as part of an international effort. Little attention was given to details of Japan's cooperation with China, largely because this would not be a popular or a politically correct thing to report. This collaboration is something that is "not" to be hyped up or promoted-but there is much potential in such cooperation. 
One of the most important aspects that is lacking in Japan's rejuvenation is whether or not Japan can work independently or outside of the auspices of the US-Japan alliance. Being in an alliance does not necessary mean that Japan cannot act alone or in concert with others. Granted, Japan does get an "A" grade for being an all-weather ally (at least under Prime Minister Abe) to the US-but the incremental willingness to deploy Japan's forces and to act in a multilateral setting certainly suggests that Prime Minister Abe's vision of the US-Japan alliance as being a "global" alliance is being operationalized. Bearing in mind that this deployment was undertaken during President Obama's era, Japan certainly has had years to prepare for this deployment and eventuality.

The value of this cooperation, however, is not in Japan's deployment to provide a much needed international public good. It is not entirely clear whether Japan did engage in combat or policing actions while undertaking this. What is truly important is also what is not said-that it is possible for Japan to cooperate with China (and not just the US) in (a) security matters, (b) humanitarian affairs, and (c) in the provision of international public goods. This type of cooperation sends a powerful message that security cooperation is indeed possible between China and Japan (and by extension South Korea), and that their interactions could transcend the economic and commercial cooperation which the two giants are so used to. This message would also undermine the assumption that China is Japan's biggest foreign policy challenge, and open up new avenues for thinking about Japan's normalization and rejuvenation. It would enable the Chinese audience to see that Japan is open to cooperation with China. Additionally, the prospects of cooperation also immediately shed light on the fact that good relations with China need not necessarily come about at the expense of the US-Japan alliance and viceversa. Japan need not give up the US-Japan alliance to work with China, in particular when it involves the provision of international public goods. It is entirely possible that more cooperation could alleviate challenges which China and Japan face in striving for a greater global role, as long as this is not framed as a "leadership" struggle. In this instance, the revolving leadership role that China and Japan undertake in the task force is important to socializing and cementing this role. 


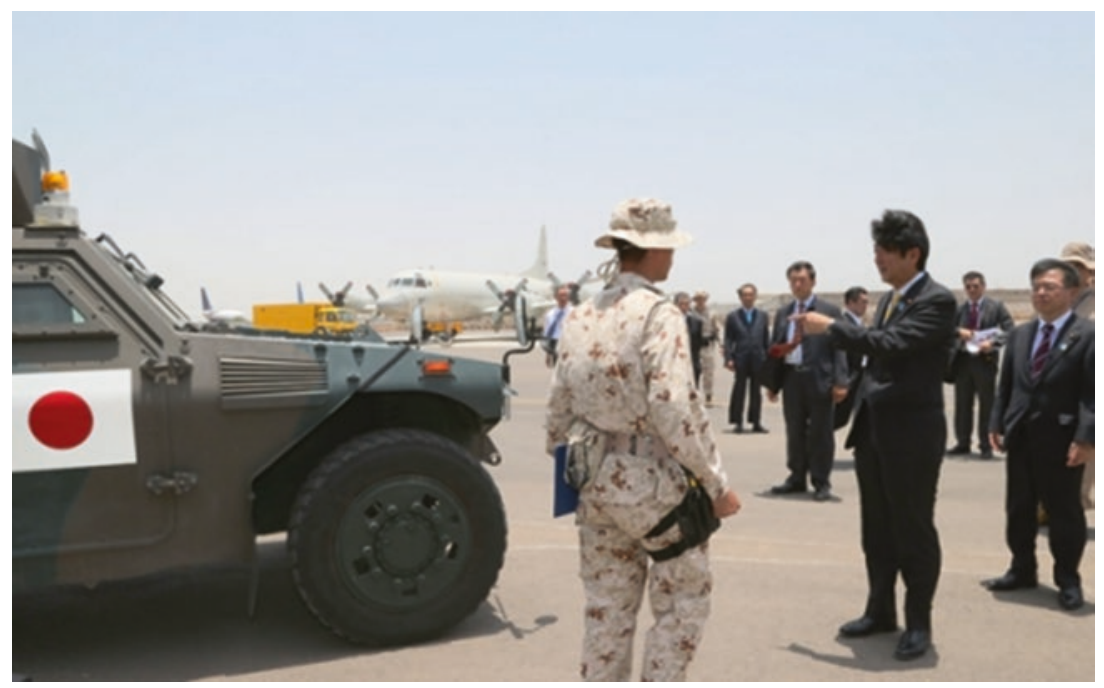

Plate: Prime Minister Abe visiting the anti-piracy base Japan established in Djibouti (East Africa). (Photo from Prime Minister's Office, Japan, https://japan.kantei. go.jp/96_abe/actions/201308/27djibouti_e.html)

\section{Conclusion}

Japan's willingness to deploy a naval group to participate in a multilateral anti-piracy mission is a major step forward in its rejuvenation as a global power. If a nation like Japan cannot assist in the provision of international public goods, then there are very few candidates left that can do this. Japan has the requisite economic strength, wealth and motivation to do this.

Due to the exigencies of circumstances, Japan's foreign policy should evolve with its changing aspirations. Indeed, Japan and China might find that their diplomacy had more room to grow if both countries could take stock of what they could achieve together. Japan's relations with China should develop in tandem with its relations with the US, perhaps on an even keel. Japan's work with China in the Gulf of Aden is a good starting point, and when properly promoted would provide the kind of confidence building that can reconcile their aspirations to an extent. At the very least, it might kick-start the relationship that by most indicators is shown to be a faltering one, at least at the time of writing. Tokyo and Beijing need to 
ensure that the traditional realpolitik maneuvers do not derail the potential cooperation both countries could undertake, particularly when the United States is pressuring third countries not to harbor any Chinese military presence, particularly in the Gulf of Aden (Lo 2017). This is the very sort of "medicine" that would help boost confidence and trust-ingredients sorely needed in Sino-Japanese relations. Japan and China should bear in mind that Asia can only become more harmonious if, and only if, both countries are able to work together. This small step in the Gulf of Aden demonstrated that China and Japan can work together (even though it had its genesis in nationalistic impulses, it ended in a joint effort). If anything, this is a case that should be promoted precisely because it could counter and erode the sensationalization and securitization of SinoJapanese relations, both at home and abroad. Japan and China might find that such a move would actually reduce the political and diplomatic frictions they have and alleviate the diplomatic burden that now plagues their foreign policies.

\section{REFERENCES}

BBC. China's anti piracy role off Somalia expands. BBC News. 29 Jan 2010, http://news.bbc.co.uk/l/hi/world/asia-pacific/8486502.stm

Beckman, R.C., Forbes, V.L., \& Grundy-Warr, C. Acts of Piracy in the Malacca and Singapore Straits. Durham: International Boundaries Research Unit, 1994.

Besley, T., Fetzer, T., \& Mueller, H. The economic costs of piracy. International Growth Centre Paper. London School of Economics and Oxford University, 2012, http://www.theigc.org/project/the-economic-costs-of-piracy/

Black, L. Debating Japan's intervention to tackle piracy in the Gulf of Aden: beyond mainstream paradigms. International Relations of Asia-Pacific 2012, $12(2), 259-85$.

Bradford, J.F. Japanese anti-piracy initiatives in Southeast Asia: policy formulation and the coastal state responses. Contemporary Southeast Asia: A Journal of International and Strategic Affairs. 2004, 26(3), 480-505.

Burnett, J. Dangerous Waters. New York: Random House Penguin Plume Books, 2003 Reprint edition.

Chan, G., Chan, L., \& Lee, P.K. China Engages Global Governance: A New World Order in the Making? London: Routledge, 2012, p 170.

CNN, South Koreans pull off daring rescue of pirated ship. January 21, 2011. CNN News. http://edition.cnn.com/2011/WORLD/asiapcf/01/21/south. korea.pirate.rescue /

Contact group on Piracy, Piracy off the Coast of Somalia. 2015. CGPCS Newsletter. http://www.lessonsfrompiracy.net/files/2015/03/CGPCS-NewsletterMarch-20152.pdf 
Contact Group on Piracy off the Coast of Somalia. First Communique, 14 Jan 2009, http://www.lessonsfrompiracy.net/files/2015/03/Communique_lst_ Plenary.pdf

Convention on the Territorial Sea and Contiguous Zone, Apr. 29, 1958, 15 UST 1606, 516 UNTS 205. Centre for International Law. http://cil.nus.edu. $\mathrm{sg} / 1958 / 1958$-convention-on-the-territorial-sea-and-the-contiguous-zone/

Ece, N.J. The Maritime Dimension of International Security: Piracy Attacks. (2012). Maritime Security and Defense against Terrorism, ed. F. Bora Uzer. Amsterdam: IOS Press, 12.

Editorial - Naval Technology, Ka-27/28 and Ka-29 Helix, Naval Technology, https://www.naval-technology.com/projects/ka272829-helix/

Fort, B. Transnational Threats and the Maritime Domain. In Piracy, Maritime Terrorism and Securing the Malacca Straits, ed. Graham Gerard Ong-Webb. 2006, Singapore: Institute of Southeast Asian Studies, 34-36.

Fox News, Somali pirates now protecting illegal fishing ships, says UN report, citing AP. 25 July 2013, http://www.foxnews.com/world/2013/07/25/ somali-pirates-now-protecting-illegal-fishing-ships-says-un-report.html

Gokhale, N. India, China and the pirates. The Diplomat. 6 March 2012, http:// thediplomat.com/2012/03/india-china-and-the-pirates /

Halloran, R. Japan at crossroads. April 2011 Air Force Magazine 62.

Harress, C. (2013, November 4). Secret flow of Somali piracy ransoms: 179 hijacked ships generated some $\$ 400 \mathrm{M}$ in payments since 2005 . So where has it all gone? International Business Times. http://www.ibtimes.com/secret-flowsomali-piracy-ransoms-179-hijacked-ships-generated-some-400m-payments2005-so-where-has

Hopkins, D.L., \& Swarttouw, H. The Contact Group on Piracy off the Coast of Somalia: genesis, rationale and objectives. In Fighting Piracy off the Coast of Somalia: Lessons Learned from the Contact Group, ed. Thierry Tardy (Institute for Security Studies, European Union), 2014 http://www.iss.europa.eu/ uploads/media/Report_20_Piracy_off_the_coast_of_Somalia.pdf

International Chamber of Commerce, Piracy news and figures. http://www.iccwbo.org/products-and-services/fighting-commercial-crime/imb-piracyreporting-centre/piracy-news-and-figures/

Japan Ministry of Defense Anti-piracy operations off Somalia and the Gulf of Aden., 30 March 2009a. http://www.mod.go.jp/e/jdf/nol4/policy.html

Japan Ministry of Defense, A start of escorting ships by MSDF vessels in the Gulf of Aden. March 30 2009b. Press release.

Japan Ministry of Defense, Counter piracy initiatives. 2013. http://www.mod. go.jp/e/publ/w_paper/pdf/2013/39_Part3_Chapter2_Sec3.pdf

Japan Ministry of Defense, Record of mission, Escort operations conducted by MSDF units off Somalia and Gulf of Aden. 2014 November 14. Press Release http://www.mod.go.jp/e/d_act/somalia/pdf/20141114b.pdf 
Japan MOD Fight Against Piracy website 2009, Measures against Piracy off the Coast of Somalia and in the Gulf of Aden Website, http://www.mod.go. jp/e/d_act/somalia/

Kaufman, A. China's participation in anti-piracy operations in off the Horn of Africa: Drivers and Implications CAN China Studies Conference report. Virginia, USA: Centre for Naval Analyses, July 2009. http://www.cna.org/ sites/default/files/research/Piracy\%20conference\%20report.pdf

Komiss, W. and Huntzinger, L. 2011. The Economic Implications of Disruptions To Maritime Oil Choke points. CAN Analysis and Solutions, March 2011.

Lin-Greenberg, E. Dragon boats: assessing China's anti-piracy operations in the Gulf of Aden," Defense and Security Analysis, 2010, 26 (2), 213-30.

Lo, K. Japanese frogmen approached Chinese warship at Djibouti, State Media say, South China Morning Post, 2nd August 2017 https://www.scmp.com/ news/china/diplomacy-defence/article/2105024/japanese-frogmenapproached-chinese-warship-djibouti

McCormack, G., \& Norimatsu, S.O. Resistant Islands: Okinawa Confronts Japan and the United States. 2012, Washington DC: Rowman \& Littlefield Publishers.

People's Daily, China navy to send its most sophisticated ships on escort mission off to Somalia. 2008, December 27 People's Daily Online. http://en.people. $\mathrm{cn} / 90001 / 90776 / 90883 / 6562939 . \mathrm{html}$

People's Daily, Chinese naval fleets sails into the Straits of Malacca. 2009a, December 29. People's Daily Online. http://en.people.cn/90001/90776/ 90883/6564180.html

People's Daily, Hong Kong, Macao, Taiwan ships can request escort of Chinese mainland navy. 2009b, January 6. People's Daily Online. http://en.people. $\mathrm{cn} / 90001 / 90776 / 90785 / 6568223 . \mathrm{html}$

PRC State Council, Defense White Paper April 2013. State Council of China, see in particular, Section V, Safeguarding World Peace and Regional Security. Available at: http://eng.mod.gov.cn/Database/WhitePapers/index.htm

QQ News, Qiemi: zhongguo shangchuan jitui suomali haidao de mubou gushi [The story behind the merchant ship's successful defence against the Somalian pirates]. 2009, January 22. QQ News. http://news.qq.com/a/20090122/000727. htm

Roehrig, T. South Korea's anti-piracy operations in the Gulf of Aden. Global Korea Report. Harvard Kennedy School, 2015. http://belfercenter.ksg.harvard.edu/files/globalkorea_report_roehrig.pdf

Sakurai, T. The fact sheet of anti-piracy activities off the coast of Somalia and the Gulf of Aden. Japan Peacekeeping Training and Research Center, Joint Staff College, Tokyo, Japan Ministry of Defense 2013. http://www.mod.go.jp/js/ jsc/jpc/research/image/eng01.pdf

Security Council, Unanimously Adopting Resolution 1918 (2010), Calls on All States to Criminalize Piracy under National Laws, (Press Release), https:// www.un.org/press/en/2010/sc9913.doc.html 
Strait of Hormuz is chokepoint for $20 \%$ of world's oil. United States Energy Information Administration. 2012, http://www.eia.gov/todayinenergy/ detail.cfm? id $=7830$

Takeda, I. Taking the lead in regional maritime security. Japan Echo, 2004, 31(6), 47-50. This article was translated from "Nihon ga shudo suru "kaiyo anzen hosho’ no shin chitsujo," Chuo Koron, Oct 2004, 70-77.

Text of Resolution 1851. United Nations. Available at http://cil.nus.edu. sg/2008/2008-united-nations-security-council-resolution-1851-on-the-situation-in-somalia-unscr-1851/

The Economic Times, India, China and Japan coordinating in anti-piracy operations. 2012, February 1. The Economic Times. https://economictimes. indiatimes.com/news/politics-and-nation/india-china-japan-coordinatingin-anti-piracy-operations/articleshow/11716849.cms

The Guardian, No Somali hijacking in nearly a year. 2013, May 3. http://www. theguardian.com/world/2013/may/03/somali-pirate-hijacking

The Somaliland Times. Japan sets up first overseas base in Djibouti to fight piracy. 2011, June 4. http://www.somalilandtimes.net/sl/2011/488/20.shtml

UN, Security Council Resolution 1816. (2008a). United Nations. http://www. refworld.org/docid/48464c622.html

UN, Security Council Resolution 1846. (2008b). United Nations. Available at http://cil.nus.edu.sg/2008/2008-united-nations-security-council-resolution-1846-on-the-situation-in-somalia-unscr-1846/

UNCHS, Convention on the High Seas, Art. 15, Apr. 29, 1958, 13 UST 2312, 450 UNTS 11. Centre for International Law. http://cil.nus.edu.sg/rp/il/ pdf/1958\%20Convention\%20on\%20High\%20Seas-pdf.pdf

United Nations, Art 105, United Nations Convention of Law of the Sea, Dec. 10, 1982, 1833 UNTS 397. United Nations. http://www.un.org/depts/los/ convention_agreements/texts/unclos/unclos_e.pdf

United Nations Convention of Law of the Sea (UNCLOS), Dec. 10, 1982, 1833 UNTS 397. United Nations. In particular see Art 58(3). http://www.un.org/ depts/los/convention_agreements/texts/unclos/unclos_e.pdf

United Nations Security Council Resolutions on Piracy. 2012. United Nations. http://www.un.org/depts/los/piracy/piracy_documents.htm

US Department of Homeland Security, Container security initiative ports. (2014). United States Department of Homeland Security. http://www.dhs.gov/container-security-initiative-ports

US Navy News, New counter piracy task force established. (2009, August 1). America's Navy. http://www.navy.mil/submit/display.asp?story_id=41687

US Transportation Dept, Economic impact of piracy in the Gulf of Aden. 2010, http://www.marad.dot.gov/wp-content/uploads/pdf/Economic_Impact_ of_Piracy_2010.pdf 
Wagner, D., \& Cafiero, D. Japan's Influence in the Middle East, 24 Jan 2014, Huffington Post, https://www.huffingtonpost.com/daniel-wagner/japansinfluence-in-the-m_b_4159850.html

Walker, R. Inside Story of a Somali Pirate Attack. BBC News. 4th June 2009 http://news.bbc.co.uk/1/hi/world/africa/8080098.stm

Watanabe, H. A Global Perspective on National Security. Japan Echo, 34 (4), 40-44. This article originally was translated from "NATO to no taiwa ga Nihon ni tsukitsuketa mono" Chuo Koron, May 2007, 160-67.

Weitz, R. Operation Somalia: China's first expeditionary force? China Security, 2009, 5(1), 27-42. http://www.washingtonobserver.org/pdfs/Weitz.pdf

Westcott, K. Somali pirates face battles at sea. BBC News., 2008 http://news.bbc. co.uk/l/hi/world/africa/7358764.stm

Woolley, P. Japan's 1991 Minesweeping Decision: An Organizational Response. Asian Survey, 1996, 36(8), 804-817. doi:https://doi.org/10.2307/2645440

World Bank Report, Conflict in Somalia: drivers and dynamics. (January 2005). http://siteresources.worldbank.org/INTSOMALIA/Resources/conflictinsomalia.pdf

Yading wan tou tufei ji [Fighting the pirates in Aden]. 2008. http://www.china. com.cn/news/txt/2008-12/19/content_16974634.htm

Zhonguo chuanyuan yong zijiranshaodan jitui suomali haidao. Youtube, https:// www.youtube.com/watch?v=Mnq4NrR4-V8

Zhou, B. Counter-piracy operations in the Gulf of Aden: implications of PLA Navy. US-China Focus, 30 December 2013. http://www.chinausfocus.com/ peace-security/counter-piracy-in-the-gulf-of-aden-implications-for-pla-navy/

Open Access This chapter is licensed under the terms of the Creative Commons Attribution 4.0 International License (http://creativecommons.org/licenses/ by $/ 4.0 /$ ), which permits use, sharing, adaptation, distribution and reproduction in any medium or format, as long as you give appropriate credit to the original author(s) and the source, provide a link to the Creative Commons licence and indicate if changes were made.

The images or other third party material in this chapter are included in the chapter's Creative Commons licence, unless indicated otherwise in a credit line to the material. If material is not included in the chapter's Creative Commons licence and your intended use is not permitted by statutory regulation or exceeds the permitted use, you will need to obtain permission directly from the copyright holder.

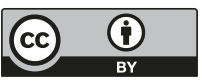

